\title{
PARAMETER DETERMINATION OF SOIL OSCILLATION LAW USING QUOTIENT OF THE RELATIVE GROWTH INCREMENTS OF OSCILLATION VELOCITY AND REDUCED DISTANCES AT "NEPRIČAVA" OPEN PIT MINE
}

\author{
ODREĐIVANJE PARAMETARA ZAKONA OSCILOVANJA TLA \\ PREKO KOLIČNIKA RELATIVNIH PRIRAŠTAJA BRZINA \\ OSCILOVANJA I REDUKOVANIH RASTOJANJA \\ NA P.K. „NEPRIČAVA“ \\ Lutovac Suzana ${ }^{1}$, Bajić Sanja ${ }^{1}$, Gaćina Radmila ${ }^{1}$, Ravilić Marina ${ }^{1}$
}

Received: May 29, 2015

Accepted: June 15, 2015

\begin{abstract}
During blasting operations, the potential energy of explosive materials is transformed into a mechanical work. That energy, in the vicinity of blasting location, destructs and crushes rock mass, a bit further creates cracks and permanent deformations in the rock mass, and even further it is being transformed into elastic deformations. The effect of elastic seismic wave is movement of particles of the rock mass from its equilibrium position. Such oscillation of the rock mass particles is manifested as a shock and represents one of the negative effects of blasting.

In order both to evaluate and control the seismic effect of blasting, as well as to plan it, the determination of soil oscillation law is required, with the strike: mine field - facilities to be protected. One of the most commonly used equations is that of M. A. Sadovski defining the law of alteration in the oscillation velocity of the soil depending on the distance, the explosive amount, and conditions of blasting and geologic characteristics of the soil, being determined on the basis of test blasting for the specific work environment.

In this paper, an analysis of the method for the determination of soil oscillation law parameters has been conducted, suggested by Profesor M. A. Sadovski. The applicability of this law was analysed on examples of mass blasting in the "Nepričava" Open Pit Mine being carried out in order to exploit the deposit.

To determine parameters in the equation of Sadovski, in addition to the common method of least squares, another model was applied. Thereby, it has been stated that both models can be used to calculate the oscillation velocity of the rock mass.
\end{abstract}

Key words: working environment, blasting, seismic effect, oscillation velocity, soil oscillation law

\footnotetext{
${ }^{1}$ University of Belgrade - Faculty of Minig and Geology, Đušina 7, 11000 Belgrade, Serbia, e-mails: suzana.lutovac@rgf.bg.ac.rs; sanjabajic@sezampro.com; radmila.gacina@rgf.rs; marina.ravilic@gmail.com
} 
Apstrakt: Pri miniranju, potencijalna energija eksploziva pretvara se u mehanički rad. Ta energija u blizini mesta miniranja razara, drobi stensku masu, nešto dalje stvara pukotine i trajne deformacije u stenskoj masi, a još dalje se pretvara u elastične deformacije. Delovanjem seizmičkog elastičnog talasa čestice stenske mase osciluju tj. pomeraju se iz svog ravnotežnog položaja. Takvo oscilovanje čestica stenskog masiva manifestuje se kao potres tla i čini jedan od negativnih efekata miniranja.

Za ocenu i kontrolu seizmičkog dejstva miniranja, kao i njegovo planiranje, neophodno je utvrditi zakon oscilovanja tla u pravcu minsko polje - objekti koji se štite. Jedna od najčešće korišćenih je jednačina M. A. Sadovskog, koja definiše zakon promene brzine oscilovanja tla u zavisnosti od rastojanja, količine eksploziva, uslova izvođenja miniranja i geoloških karakteristika tla, a određuje se na osnovu probnih miniranja za konkretnu radnu sredinu.

U ovom radu izvršena je analiza metode za određivanje parametara zakona oscilovanja tla, koji je predložio ruski profesor M. A. Sadovski. Primenljivost ovog zakona, analizirana je na primerima masovnih miniranja na P.K. „Nepričava“, koja se izvode radi eksploatacije ležišta.

Za određivanje parametara u jednačini Sadovskog, pored uobičajene metode najmanjih kvadrata primenjen je još jedan model. Pri tom je konstatovano da se oba modela mogu koristiti za izračunavanje brzine oscilovanja stenske mase.

Ključne reči: radna sredina, miniranje, seizmičko dejstvo, brzina oscilovanja, zakon oscilovanja tla

\section{INTRODUCTION}

As the relation between the soil oscillation velocity and basic parameters affecting its magnitude, being: the amount of explosive, a distance from the blast site, characteristics of the rock material and a type of blasting, the equation of M.A. Sadovski, where the oscillation velocity $v$ is given in the form of the function, is most frequently used:

$$
v=K \cdot R^{-n}
$$

where $R$ is a reduced distance, and $K$ and $n$ parameters conditioned by soil characteristics and blasting conditions, thereby $v$ is the decreasing convex function of the variable $R$.

By the application of the law of rock mass oscillation while blasting, the determination of the soil oscillation velocity is enabled for each blast operation in advance, thus blasting is, as regards seismic effect, under control, which gives an opportunity to plan the magnitude of shock waves for each future blast operation (Trajković et al. 2005).

In this manner, the negative effects of blasting are reduced, production efficiency is increased and, at the same time, building structures, mining facilities and the environment near blasting location are protected as well. 


\section{SOIL OSCILLATION LAW}

To establish the correlation between the oscillation velocity and three basic parameters affecting its size: the explosive quantity, properties of rock material and the distance, there have been developed several mathematical models in the world. One of most frequently used models, i.e. equations, is the equation of Sadovski defining the law on velocity alteration of soil oscillation depending on the distance, the explosive quantity, and the way of blasting (Медведев, 1964). The law defined in this way offers the possibility to determine the seismic effect of blasting towards a facility or a settlement, whereby the connection, between the velocity of soil oscillation and consequences that can affect facilities, is used. The equation of M.A. Sadovski is given in the form:

$$
v=K \cdot\left(\frac{r}{\sqrt[3]{Q}}\right)^{-n}
$$

where there are:

$v$ - velocity of soil oscillation $[\mathrm{cm} / \mathrm{s}]$,

$K$ - a coefficient conditioned by soil characteristics and blasting conditions determined by terrain surveying,

$n$ - the exponent, conditioned by soil properties and mining conditions and determined by field measurements as well,

$r$ - distance from the blast site to the monitoring point [m],

$Q$ - amount of explosive $[\mathrm{kg}]$.

\subsection{Derivation of equation of rock mass oscillation law}

If, by blasting in the specific environment, the relative increase in the oscillation velocity of the rock mass and the relative increase of the reduced distance are monitored, then it can be seen that their relations at various levels have approximately the same value (Lutovac, 2010) which will be marked $(-n)$, meaning that:

$$
\frac{\frac{\Delta v}{v}}{\frac{\Delta R}{R}} \approx-n
$$

Thereby it can be considered that:

$$
\lim _{\Delta R \rightarrow 0} \frac{\frac{\Delta v}{v}}{\frac{\Delta R}{R}}=-n
$$

which means that is: 


$$
\frac{\frac{d v}{v}}{\frac{d R}{R}}=-n
$$

The equation (3) can be written in the form: $\frac{d v}{v}=-n \cdot \frac{d R}{R}$, where by integration it is obtained:

$$
\int \frac{d v}{v}=-n \cdot \int \frac{d R}{R}
$$

namely:

$$
\log v=\log R^{-n}+\log K
$$

where is $K$ constant of integration.

The equation (4) can be written in the form:

$$
\log v=\log k \cdot R^{-n}
$$

from where it is obtained:

$$
v=K \cdot R^{-n}
$$

being the equation of rock mass oscillation of M. A. Sadovski.

The equation of Sadovski is commonly shown in the form:

$$
v=K \cdot Q_{\text {red }}^{n}
$$

where is $Q_{\text {red }}$ reduced amount of explosive:

$$
Q_{\text {red }}=\frac{\sqrt[3]{Q}}{r}
$$

where is:

$r$ - the distance from the blast site to the monitoring point [m],

$Q$ - overall amount of explosive in a mine series $[\mathrm{kg}]$.

\subsection{Models of determination of soil oscillation law parameters}

There are two parameters $K$ and $n$ in the equation (5) which should be determined for the specific work environment and by particular blasting conditions. With regard to the characteristics of the rock mass oscillation law, it is possible to determine the parameters $K$ and $n$ in a number of ways, i.e. models, thereby using values obtained by experimental measurements.

Determination of parameters by model 1

The smallest square method is mainly used to obtain the parameters $K$ and $n$ which represents a common model (Simeunović, 1985).

Determination of parameters by model 2

Proceeding from the rock mass oscillation law from the equation (5):

$$
v=K \cdot R^{-n}
$$


which is derived in this study, whereas the parameter $K$, which appeared as a constant of integration (Lutovac, 2010), we can determine from the condition (initial condition) that for $R=R_{l}$ shall be $v=v_{l}$.

Parameters $K$ and $n$ will be determined by using experimental data of pairs $R_{i}$ and $v_{i}, i=1,2, \ldots, N$, provided that the curve of the oscillaion velocity of rockmass passes through the point $M_{l}\left(R_{l}, v_{l}\right)$. In that case out of (5) for $R=R_{l}$ and $v=v_{l}$ we obtain:

$$
v_{1}=K \cdot R_{1}^{-n} \quad \text { where is: } K=v_{1} \cdot R_{1}^{-n}
$$
equation:

By the replacement of values for $K$ from (8) in the equation (5) we obtain the

$$
v=v_{1} \cdot\left(\frac{R_{1}}{R}\right)^{n}
$$

From the equation (9), for $R=R_{1}$ there is obtained $v=v_{1}$ for any $n$, in our case $n>0$. For $R=R_{1}, i=2,3, \ldots, N$, from the equation (9), we can take that:

$$
v_{i}=v_{1} \cdot\left(\frac{R_{1}}{R_{i}}\right)^{n} \quad i=2,3, \ldots, N
$$

from where the relation is obtained:

$$
v_{1} \cdot v_{2} \cdot \ldots \cdot v_{N}=v_{1}^{N} \cdot\left(\frac{R_{1}^{N}}{R_{1} \cdot R_{2} \cdot \ldots \cdot R_{N}}\right)^{n}
$$

From the relation (10), we can determine parameter $n$. By logharithm operation of relation (10) we obtain:

$$
n \log \left(\frac{R_{1}^{N}}{R_{1} \cdot R_{2} \cdot \ldots \cdot R_{N}}\right)=\log \left(\frac{v_{1} \cdot v_{2} \cdot \ldots \cdot v_{N}}{v_{1}^{N}}\right)
$$

where we find:

$$
n=\frac{\log \left(\frac{v_{1} \cdot v_{2} \cdot \ldots \cdot v_{N}}{v_{1}^{N}}\right)}{\log \left(\frac{R_{1}^{N}}{R_{1} \cdot R_{2} \cdot \ldots \cdot R_{N}}\right)}
$$

By the replacement of the value for the parameter $n$ in the equation (11), found in this way, we obtain the relation for the oscillation velocity of rock mass in the monitored environment:

$$
v=v_{1} \cdot\left(\frac{R_{1}}{R}\right)^{n}
$$

Thus, to determine the parameter $n$, all experimental data were taken into account.

\section{DEFINING OF STATISTICAL CRITERIA}

To evaluate the degree (Ivanović, 1973) of correlation between recorded (measured) and calculated data in this paper we have used the coefficient of linear 
correlation $r$ (Simonović, 1995) between the logarithm of reduced distance $R$ and the logarithm of the oscillation velocity $v$. Additionally, we have also taken into account the curveline dependency index $\rho$ (Vukadinović, 1970) between the reduced distance $R$ and the oscillation velocity $v$.

The evaluation of the relationship degree of two variables (Lutovac, 2010) to values of the curveline dependency index $\rho$ is given in the following survey:

- $\quad 0<\rho<0.2$ - none or highly poor correlation;

- $\quad 0.2<\rho<0.4$ - poor correlation;

- $\quad 0.4<\rho<0.7$ - significant coorelation;

- $\quad 0.7<\rho<1.0$ - strong or highly strong correlation.

The same is valid for the absolute value of linear correlation coefficient $r$.

As a convenience measure of the obtained functional relationship for the given experimental data, the criterion " $3 S^{\text {" }}$ was also used (Vukadinović, 1970). This criterion uses squares of differences between the obtained experimenal data and the calculated ones for oscillation velocities of $v$. If those diffrences are one after another $\varepsilon_{1}, \varepsilon_{2}, \ldots, \varepsilon_{\mathrm{N}}$, then it is:

$$
S=\sqrt{\frac{\varepsilon_{1}^{2}+\varepsilon_{2}^{2}+\ldots+\varepsilon_{N}^{2}}{N}}
$$

According to this criterion, for the evaluation of convenience of the obtained functional correlation, the following relations are valid:

- if it is $\left|\varepsilon_{\max }\right| \geq 3 S$, the obtained functional correlation is rejected as unfavourable;

- $\quad$ if it is $\left|\varepsilon_{\max }\right|<3 S$, the functional correlation is accepted as a good one.

\section{REVIEW OF MASSIVE BLASTING AT "NEPRIČAVA" OPEN PIT MINE NEAR LAJKOVAC}

\subsection{General characteristics of "Nepričava" Open Pit Mine}

The limestone deposit "Nepričava" is situated at a distance of about $7.0 \mathrm{~km}$ west of town of Lajkovac, along the road and railroad Lajkovac - Valjevo, on the left bank of Kolubara River in the nearest vicinity of village of Slovac.

The limestone deposit "Nepričava" is consisted of rock masses of sedimentary origin, which are not entirely homogeneous in composition. Limestones are the most important lithological members from both economic aspect and aspect of mining exploitation technology. Physical and mechanical properties of limestone in the deposit are spatially very uneven (Trajković et al. 2013).

By examination of physical and mechanical properties of the working environment, the following results were obtained:

$\begin{array}{lll}\text { - } & \text { Compressive strength } & \text { (21.1 to } 93.0) \mathrm{MPa} \\ \text { - } & \text { Volume weight } & \text { (17.1 to } 26.3) \mathrm{kN} / \mathrm{m}^{3} \\ \text { - } & \text { Density } & (0.97 \text { to } 0.99) \mathrm{kN} / \mathrm{m}^{3} \\ \text { - } & \text { Porosity } & (0.0004 \text { to } 0.026) \% \\ \text { - } & \text { Water suction } & (0.08 \text { to } 0.23) \%\end{array}$




\subsection{Blasting Method}

Measurements of seismic shocks at "Nepričava" surface mine were performed during blasting, conducted for the purpose of deposit exploitation (Trajković \& Lutovac, 2006). Three blasting operations were performed.

Balkanit 60/1000 and Videksil 65/2000 are used as explosive materials. The activation of explosives in boreholes was performed using detonating fuse $\mathrm{C}-12$, while initiating of detonating fuse was performed with blasting cap No.8. Decelerators between boreholes have had the interval delay of $20 \mathrm{~ms}$.

Basic data related to the number of boreholes $N_{b}$, the overall explosive amount $Q_{u k}$, the maximal exsplosive amount by deceleration interval $Q_{i}$, overall borehole depth $L_{u k}$, and average stemming length $L_{p c}$, are presented in Table 1 .

Table 1 - Survey of blasting parameters

\begin{tabular}{|c|c|c|c|c|c|}
\hline Blasting & $\boldsymbol{N}_{\boldsymbol{b}}$ & $\begin{array}{c}\boldsymbol{Q}_{\boldsymbol{u k}} \\
{[\mathbf{k g}]}\end{array}$ & $\begin{array}{c}\boldsymbol{Q}_{\boldsymbol{i}} \\
{[\mathbf{k g}]}\end{array}$ & $\begin{array}{c}\boldsymbol{L}_{\boldsymbol{u k}} \\
{[\mathbf{m}]}\end{array}$ & $\begin{array}{c}\boldsymbol{L}_{\boldsymbol{p c}} \\
{[\mathbf{m}]}\end{array}$ \\
\hline \hline I & 8 & 185.0 & 26 & 80.0 & 3.0 to 3.2 \\
\hline II & 7 & 135.0 & 20.0 & 70.0 & 3.0 to 3.2 \\
\hline III & 7 & 105.0 & 19.0 & 61.0 & 3.0 to 3.2 \\
\hline
\end{tabular}

The record of soil oscillation velocity for blasting number III - measuring point 4 is shown in Figure 1.

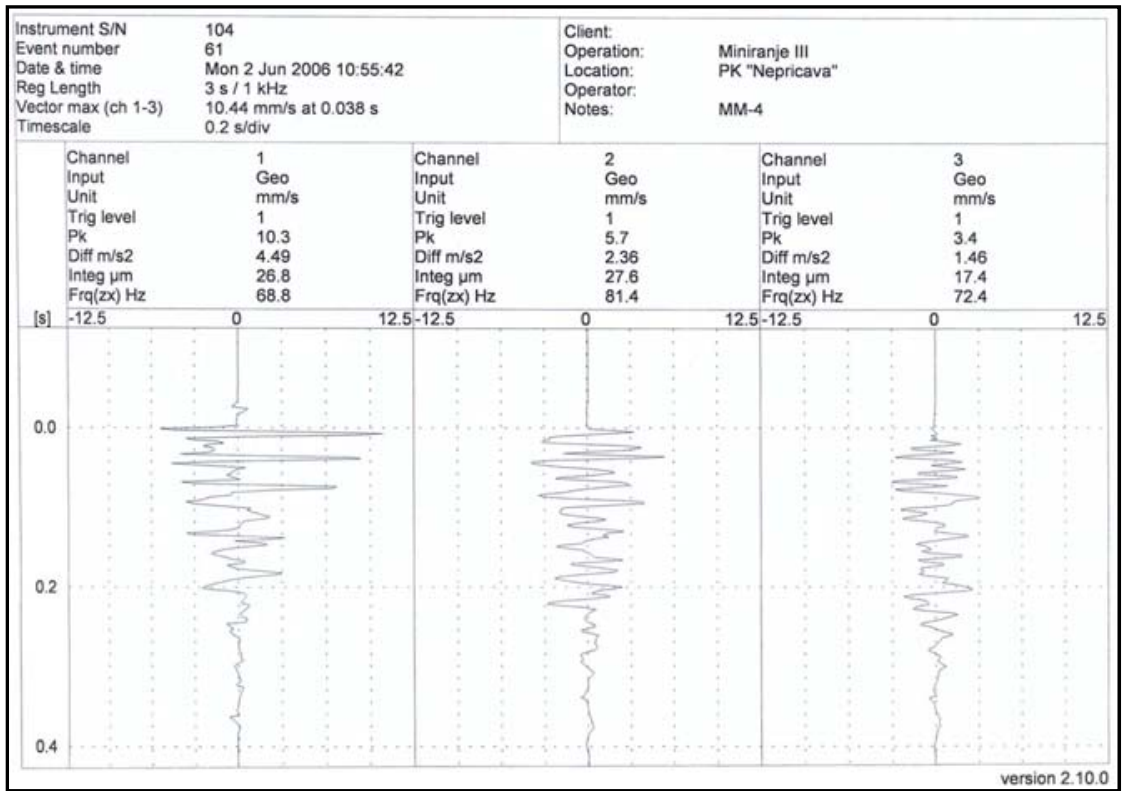

Figure 1 - Image of soil oscillation velocity for blasting III-MM4 


\subsection{Calculation of soil oscillation law parameters}

Values of distances from blast sites to monitoring points $r$, the amount of explosive $Q$, calculated values of reduced distances $R$, recorded values of soil oscillation velocities by components $v_{t}, v_{v}, v_{l}$ and resulting oscillation velocities $v_{r e z}$ for blasting from I to III of totally five measuring points MM are given in Table 2.

Table 2 - Survey of blasting parameters and measurement results

\begin{tabular}{|c|c|c|c|c|c|c|c|c|c|}
\hline $\mathbf{N}^{\mathbf{O}}$ & Blasting & $\mathbf{M M}$ & $\begin{array}{c}\boldsymbol{r} \\
{[\mathbf{m}]}\end{array}$ & $\begin{array}{c}\boldsymbol{Q} \\
{[\mathbf{k g}]}\end{array}$ & $\boldsymbol{R}$ & $\begin{array}{c}\boldsymbol{v}_{\mathbf{t}} \\
{[\mathbf{c m} / \mathbf{s}]}\end{array}$ & $\begin{array}{c}\boldsymbol{v}_{\mathbf{v}} \\
{[\mathbf{c m} / \mathbf{s}]}\end{array}$ & $\begin{array}{c}\boldsymbol{v}_{\mathbf{I}} \\
{[\mathbf{c m} / \mathbf{s}]}\end{array}$ & $\begin{array}{c}\boldsymbol{v}_{\text {rez }} \\
{[\mathbf{c m} / \mathbf{s}]}\end{array}$ \\
\hline \hline 1 & I & $\mathrm{MM}-1$ & 256.90 & 185.0 & 45.0858 & 0.117 & 0.136 & 0.110 & 0.2104 \\
\hline 2 & I & $\mathrm{MM}-2$ & 220.81 & 185.0 & 38.7521 & 0.199 & 0.296 & 0.227 & 0.4228 \\
\hline 3 & I & $\mathrm{MM}-3$ & 224.58 & 185.0 & 39.4137 & 0.174 & 0.313 & 0.160 & 0.3922 \\
\hline 4 & I & $\mathrm{MM}-4$ & 161.78 & 185.0 & 28.3923 & 0.267 & 0.417 & 0.237 & 0.5490 \\
\hline 5 & I & $\mathrm{MM}-5$ & 179.10 & 185.0 & 31.4320 & 0.217 & 0.211 & 0.124 & 0.3271 \\
\hline \hline 6 & II & $\mathrm{MM}-1$ & 184.41 & 135.0 & 35.9479 & 0.195 & 0.171 & 0.110 & 0.2817 \\
\hline 7 & II & $\mathrm{MM}-2$ & 151.52 & 135.0 & 29.5365 & 0.341 & 0.276 & 0.253 & 0.5064 \\
\hline 8 & II & $\mathrm{MM}-3$ & 152.79 & 135.0 & 29.7840 & 0.372 & 0.466 & 0.221 & 0.6359 \\
\hline 9 & II & $\mathrm{MM}-4$ & 87.57 & 135.0 & 17.0704 & 1.170 & 0.821 & 0.615 & 1.5560 \\
\hline 10 & II & $\mathrm{MM}-5$ & 99.91 & 135.0 & 19.4759 & 0.370 & 0.480 & 0.304 & 0.6780 \\
\hline \hline 11 & III & $\mathrm{MM}-1$ & 137.43 & 105.0 & 29.1308 & 0.285 & 0.254 & 0.180 & 0.4221 \\
\hline 12 & III & $\mathrm{MM}-2$ & 137.33 & 105.0 & 29.1096 & 0.300 & 0.376 & 0.246 & 0.5403 \\
\hline 13 & III & $\mathrm{MM}-3$ & 72.09 & 105.0 & 15.2808 & 1.030 & 0.565 & 0.339 & 1.2227 \\
\hline 14 & III & $\mathrm{MM}-4$ & 77.99 & 105.0 & 16.5314 & 0.337 & 0.256 & 0.315 & 0.5276 \\
\hline
\end{tabular}

On the basis of data given in Table 2, the soil oscillation law is calculated by the formula (5) - by the models 1 and 2. The calculation of the curve was carried out for values of reduced distances from $R=15.2808$ to $R=45.0858$. Thus curve parameters were calculated enabling us to determine the equation of soil oscillation in the form of:

$$
\text { Model } 1 \quad v_{1}=34.0616 \cdot R^{-1.2663}
$$

whereby linear dependence between $\log v$ and $\log R$ has been obtained, expressed by the equation (13), with the linear correlation coefficient $r$ amounting: $r=-0.8288$.

Graphic survey of soil oscillation law is shown in Figure 2.

$$
\text { Model } 2 \quad v_{2}=69.3490 \cdot R^{-1.4810}
$$

On the basis of the obtained equations of soil oscillation (13) and (14), it is possible to calculate values of soil oscillation velocities for corresponding reduced distances for models 1 and 2 .

In Table 3, there is presented the survey of reduced distances $R$, recorded oscillation velocities $v_{r}$, calculated oscillation velocities $v_{i l}, v_{i 2}$, as well as the difference between recorded and calculated soil oscillation velocities for models 1 and 2 . 


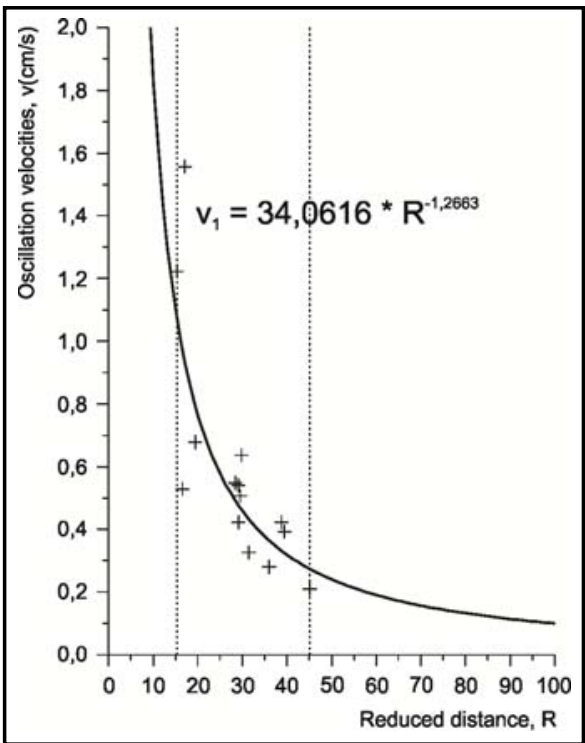

Figure 2 - Graphic survey of soil oscillation law curve in "Nepričava" Open Pit Mine

Table 3 - Survey of recorded and calculated soil oscillation velocities for models 1 and 2

\begin{tabular}{|c|c|c|c|c|c|c|}
\hline $\mathbf{N}^{\mathbf{O}}$ & $\boldsymbol{R}$ & $\begin{array}{c}\boldsymbol{v}_{\boldsymbol{r}} \\
{[\mathbf{c m} / \mathbf{s}]}\end{array}$ & $\begin{array}{c}\boldsymbol{v}_{\boldsymbol{i} 1} \\
{[\mathbf{c m} / \mathbf{s}]}\end{array}$ & $\begin{array}{c}\boldsymbol{v}_{\boldsymbol{i} 2} \\
{[\mathbf{c m} / \mathbf{s}]}\end{array}$ & $\begin{array}{c}\boldsymbol{v}_{\boldsymbol{r}}-\boldsymbol{v}_{\boldsymbol{i} 1} \\
{[\mathbf{c m} / \mathbf{s}]}\end{array}$ & $\begin{array}{c}\boldsymbol{v}_{\boldsymbol{r}}-\boldsymbol{v}_{\boldsymbol{i} 2} \\
{[\mathbf{c m} / \mathbf{s}]}\end{array}$ \\
\hline \hline 1 & 45.0858 & 0.2104 & 0.2740 & 0.2463 & -0.0636 & -0.0359 \\
\hline 2 & 38.7521 & 0.4228 & 0.3319 & 0.3082 & +0.0909 & +0.1146 \\
\hline 3 & 39.4137 & 0.3922 & 0.3249 & 0.3005 & +0.0673 & +0.0917 \\
\hline 4 & 28.3923 & 0.5490 & 0.4921 & 0.4885 & +0.0569 & +0.0605 \\
\hline 5 & 31.4320 & 0.3271 & 0.4327 & 0.4202 & -0.1056 & -0.0931 \\
\hline \hline 6 & 35.9479 & 0.2817 & 0.3650 & 0.3444 & -0.0833 & -0.0627 \\
\hline 7 & 29.5365 & 0.5064 & 0.4681 & 0.4607 & +0.0383 & +0.0457 \\
\hline 8 & 29.7840 & 0.6359 & 0.4632 & 0.4551 & +0.1727 & +0.1808 \\
\hline 9 & 17.0704 & 1.5560 & 0.9373 & 1.0377 & +0.6187 & +0.5183 \\
\hline 10 & 19.4759 & 0.6780 & 0.7932 & 0.8537 & -0.1152 & -0.1757 \\
\hline \hline 11 & 29.1308 & 0.4221 & 0.4764 & 0.4703 & -0.0543 & -0.0482 \\
\hline 12 & 29.1096 & 0.5403 & 0.4768 & 0.4708 & +0.0635 & +0.0695 \\
\hline 13 & 15.2808 & 1.2227 & 1.0784 & 1.2227 & +0.1443 & 0 \\
\hline 14 & 16.5314 & 0.5276 & 0.9762 & 1.0882 & -0.4486 & -0.5606 \\
\hline
\end{tabular}

Based on the data in Table 3, a statistical analysis was carried out and the following values were obtained:

\section{For model 1:}

The curveline dependency index $\rho_{1}$ between the reduced distance $R$ and soil oscillation velocity $v$ is:

$\rho_{1}=0.7786$ - there is a strong correlation between $R$ and $v$, given in the formula (13). 
The maximum differnce between the recorded and calculated oscillation velocities of the soil $\varepsilon_{\max }=\max \left|\varepsilon_{i}\right|$, amounts:

$\varepsilon_{\max 1}=0.6187 ; \quad S_{1}=0.2226 ; \quad 3 S_{1}=0.6678$

As there is $\varepsilon_{\max 1}<3 S_{1}$, supposed functional relationship is accepted as a good one.

For model 2:

$\rho_{2}=0.7782$ - there is a strong correlation between $R$ and $v$, given in the formula (14).

$\varepsilon_{\max 2}=0.5606 ; \quad S_{2}=0.2228 ; \quad 3 S_{2}=0.6683$

$\varepsilon_{\max 2}<3 S_{2}$, supposed functional relationship is accepted as a good one.

\section{CONCLUSION}

To establish the relationship between the oscillation velocity of the rock mass and basic parameters affecting its magnitude, being: the amount of explosive, the distance from the blast site, characteristics of the rock mass and the type of blasting, it is the equation of M. A. Sadovski that is used most commonly.

In this paper, the law of Sadovsky is derived using the quotient of the relationship between relative growth of oscillation velocity of the rock mass and relative growth of reduced distances. Thereby, in a marginal case, a differential equation, whose general integral overlaps with the law of Sadovski, is obtained.

Parameters $n$ and $K$ in the law of Sadovsky were determined in two ways models in a given working environment in the open pit mine "Nepričava". Thereby corresponding functiones have been obtained presenting oscillation velocities of the rock mass depending on a reduced distance. The calculated corresponding indexes of the curveline correlation point out that there is a highly strong curveline relationship between a reduced distance and the oscillation velocity of the rock mass expressed in the obtained functions.

Comparing values of the recorded oscillation velocities of the rock mass with the corresponding calculated ones, it can be seen that they are approximately the same. On the basis of obtained values of curveline dependency coefficients and the values of linear correlation coefficients between the reduced distance logarithm and the oscillation velocity logarithm, we can conclude that both models can be used for calculating of the oscillation velocity of the rock mass.

\section{ACKNOWLEDGEMENT}

This paper has resulted from the Project No.33025 and No.33029 financed by the Ministry of Education of the Republic of Serbia realized by the Faculty of Mining and Geology in Belgrade. 


\section{REFERENCES}

[1] IVANOVIĆ, B. (1973) Teorijska statistika. Beograd: Naučna knjiga.

[2] LUTOVAC, S. (2010) Model određivanja parametara zakona oscilovanja stenske mase pri miniranju. Doktorska disertacija, Univerzitet u Beogradu Rudarsko-geološki fakultet.

[3] Медведев, С.В. 1964) Сеисмика горных взрывов. Москва: Недра.

[4] SAVIĆ, M. (2000) Miniranje na površinskim kopovima. Bor: Institut za bakar Bor.

[5] SIMEUNOVIĆ, D. (1985) Matematika. Beograd: Rudarsko-geološki fakultet Univerziteta u Beogradu.

[6] SIMONOVIĆ, V. (1995) Uvod u teoriju verovatnoće i matematičku statistiku. Beograd: Tekon - Tehnokonsalting.

[7] TRAJKOVIĆ, S., SLIMAK, Š., LUTOVAC, S. (2005) Tehnika miniranja i potresi. Beograd: Rudarsko-geološki fakultet Univerziteta u Beogradu.

[8] TRAJKOVIĆ S., LUTOVAC S. (2006): Studija seizmičkih uticaja na okolne građevinske objekte kao posledica izvođenja miniranja na PK "Nepričava" Lajkovac. Beograd: Rudarsko-geološki fakultet Univerziteta u Beogradu.

[9] TRAJKOVIĆ, S., LUTOVAC, S. and RAVILIĆ, M. (2013) Assessment of impact on environment and constructed facilities owing to blasting at open pit mine "Nepričava". Underground Mining Engineering, 22, pp. 33-48.

[10] VUKADINOVIĆ, S. (1970) Elementi računa verovatnoće $i$ matematičke statistike. Beograd: Tehnika za umnožavanje Biroa za građevinarstvo. 